\title{
Nasal saline as a placebo in a rhinosinusitis study
}

\author{
This article was published in the following Dove Press journal: \\ Drug Design, Development and Therapy \\ 20 August 2014 \\ Number of times this article has been viewed
}

\begin{abstract}
Ahmet Karadag'
Ferhat Catal ${ }^{2}$

'Division of Neonatology, ${ }^{2}$ Division of Pediatric Allergy Department of Pediatrics, School of Medicine, Inonu University, Malatya, Turkey
\end{abstract}

\section{Dear editor}

I read with interest Mainz et al's article in the February issue of your journal. ${ }^{1}$ The authors concluded that sinonasal inhalation of vibrating antibiotic aerosols appears promising for reducing pathogen colonization of paranasal sinuses and for control of symptoms in patients with cystic fibrosis. We have an objection to their study methods.

It is well known that isotonic saline solution nasal washing facilitates nasal drainage and cleans the airway of any postnasal discharge (including allergens); furthermore, it can be effective when applied appropriately. ${ }^{2-6}$ Isotonic saline solution is applied (five dropperfuls in each nostril) at least four times a day until the symptomatology subsides. ${ }^{2}$ In addition, isotonic saline solution irrigation has been found to reduce inflammatory mediators (histamine, prostaglandin $\mathrm{D}_{2}$, and leukotriene $\mathrm{C}_{4}$ ) and allergens in nasal secretions. ${ }^{7}$ For these reasons, nasal washing with saline is effective against pathologies of the upper respiratory tract that occur via inflammatory mediators, namely, the common cold, acute and chronic sinusitis, and, in particular, rhinitis. ${ }^{7}$

As a result, nasal saline, administered with the correct technique, can be as effective as nasal drugs; therefore, it cannot be used as a placebo in a rhinosinusitis study.

\section{Disclosure}

The author reports no conflicts of interest in this communication.

\section{References}

1. Mainz JG, Schädlich K, Schien C, et al. Sinonasal inhalation of tobramycin vibrating aerosol in cystic fibrosis patients with upper airway Pseudomonas aeruginosa colonization: results of a randomized, double-blind, placebo-controlled pilot study. Drug Des Devel Ther. 2014;8:209-217.

2. Ozsoylu S. Nose drops at the common cold. Eur J Pediatr. 1985;144(3):294.

3. Karadag A. Nasal saline for acute sinusitis. Pediatrics. 2002;109(1):165.

4. Karadag A, Kurtaran H, Tekin O, Uraldi C, Aydogan T. Isotonic saline or hypertonic saline: which is best for sinusitis? J Fam Pract. 2004;53(8):637.

5. Akarçay M, Fırat YM, Kelleş M. [Rhinosinusitis in children and adults]. J Turgut Ozal Med Cent. 2010;17(1):65-70. Turkish.

6. Uras N, Karadag A, Kurtaran H, Yilmaz T. Nasal saline: placebo or drug? Ann Allergy Asthma Immunol. 2004;93(1): 104

7. Georgitis JW. Nasal hyperthermia and simple irrigation for perennial rhinitis. Changes in inflammatory mediators. Chest. 1994;106:1487-1492.
Department of Pediatrics, Division of Pediatric Allergy, School of Medicine, Inonu University, Seyrentepe Mah, Florya Park Sitesi, No:6, 44000, Malatya, Turkey Email ferhatcatal@gmail.com 


\section{Authors' reply}

Jochen G Mainz

Christin Arnold

Cystic Fibrosis Centre, Jena University Hospital, Jena, Germany

Correspondence: Jochen G Mainz

Pediatric Pulmonology, Cystic Fibrosis Centre for Children and Adults, Jena University Hospital, Kochstrasse 2, 07745 Jena, Germany

Tel +49364I 938425

Fax +493641938314

Email jochen.mainz@med.uni-jena.de

\section{Dear editor}

We agree with Ahmet Karadag's comment that isotonic saline as an adjunct treatment, regularly performed with nasal douches of the upper airways with $250 \mathrm{~mL}$ of isotonic saline, can have positive effects on upper airway symptoms. ${ }^{1}$ Apart from removing secretions and crusts, this therapeutic nasal lavage can also reduce the nasal load of allergens and pathogens, as well as of inflammatory mediators.

Regarding our present trial, we estimate that approximately $1 \mathrm{~mL}$ of isotonic saline or tobramycin solution should have reached the nasal cavity and paranasal sinuses during sinonasal inhalation with the PARI Sinus ${ }^{\mathrm{TM}}$ nebulizer (PARI Corp, Starnberg, Germany). ${ }^{2}$ Therefore, the physical effect of cleansing the sinonasal space within our trial should not be overestimated, and we would expect similar effects in both therapeutic arms of our study.

The objection of Karadag regarding the choice of isotonic saline as placebo should be discussed in regard to the primary endpoint of our trial: Pseudomonas aeruginosa colony count in diagnostic nasal lavage. We presented the method in a recent publication by our group, ${ }^{3}$ in which a video was supplied for training issues.

Most interestingly, saline solutions have the potential to reduce bacterial motility, as well as the ability to perform biofilms, and even exhibit a bactericidal potential. This was assessed in a very recent trial by Michon et al, ${ }^{4}$ who studied the in vitro effects of different concentrations of saline on P. aeruginosa isolated from the respiratory tract of cystic fibrosis patients. Applying a 10\% hypertonic solution, bactericidal activity on $90 \%$ of the isolates was found. As visualized in Figure 1, hypertonic saline of lower concentrations also had bactericidal effects. However, isotonic saline was not shown to have different effects on bacterial growth in comparison to distilled water, even if the pathogens' motility appeared to be slightly reduced. ${ }^{4}$

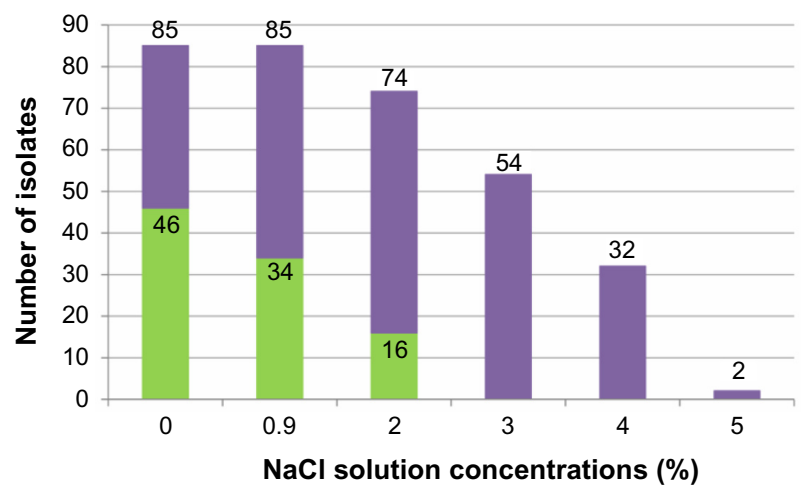

Figure I Rate of motile Pseudomonas aeruginosa isolates according to $\mathrm{NaCl}$ concentration.

Notes: Green bars show the number of motile isolates among isolates with noninhibited growth (full bars). Reprinted with permission from Michon AL, JumasBilak E, Chiron R, Lamy B, Marchandin H. Advances toward the elucidation of hypertonic saline effects on Pseudomonas aeruginosa from cystic fibrosis patients. PLoS One. 2014;9(2):e90164. ${ }^{4}$

As the described dose-dependent growth inhibition of saline solutions does not apply to isotonic saline, the use of isotonic saline does not relevantly bias the results of the primary endpoint of our study. Conclusively, isotonic saline is appropriate for use as a placebo when compared to an antibiotic treatment.

In parallel to our publication on pulsating sinonasal inhalation with tobramycin, ${ }^{5}$ we published a trial on sinonasal inhalation of dornase alfa in the Journal of Cystic Fibrosis (JCF). ${ }^{2}$ As a control substance for the recombinant mucolytic designed for cystic fibrosis, ${ }^{6}$ we also applied isotonic saline.

Karadag submitted a very similar letter to the editor to JCF, equally objecting to the use of isotonic saline as a placebo. As sinonasal symptoms, which were assessed in the DDDT publication as a secondary outcome parameter, were the primary endpoint in our JCF article, we would like to discuss this issue in our response to Karadag's letter submitted to JCF.?

\section{Disclosure}

The authors report no conflicts of interest in this communication.

\section{References}

1. Kassel JC, King D, Spurling GK. Saline nasal irrigation for acute upper respiratory tract infections. Cochrane Database Syst Rev. 2010;(3):CD006821.

2. Mainz JG, Schien C, Schiller I, et al. Sinonasal inhalation of dornase alfa administered by vibrating aerosol to cystic fibrosis patients: a double-blind placebo-controlled cross-over trial. J Cyst Fibros. 2014;13(4):461-470.

3. Hentschel J, Müller U, Doht F, et al. Influences of nasal lavage collection-, processing- and storage methods on inflammatory markers - evaluation of a method for non-invasive sampling of epithelial lining fluid in cystic fibrosis and other respiratory diseases. J Immunol Methods. 2014;404:41-51. 
4. Michon AL, Jumas-Bilak E, Chiron R, Lamy B, Marchandin H. Advances toward the elucidation of hypertonic saline effects on Pseudomonas aeruginosa from cystic fibrosis patients. PLoS One. 2014;9(2):e90164.

5. Mainz JG, Schädlich K, Schien C, et al. Sinonasal inhalation of tobramycin vibrating aerosol in cystic fibrosis patients with upper airway Pseudomonas aeruginosa colonization: results of a randomized, double-blind, placebo-controlled pilot study. Drug Des Devel Ther. 2014;8:209-217.
6. Konstan MW, Ratjen F. Effect of dornase alfa on inflammation and lung function: potential role in the early treatment of cystic fibrosis. $J$ Cyst Fibros. 2012;11(2):78-83.

7. Mainz JG, Michl R, Arnold C. Response to Karadag. J Cyst Fibros. In press 2014

\section{Publish your work in this journal}

Drug Design, Development and Therapy is an international, peerreviewed open-access journal that spans the spectrum of drug design and development through to clinical applications. Clinical outcomes, patient safety, and programs for the development and effective, safe, and sustained use of medicines are a feature of the journal, which has also been accepted for indexing on PubMed Central. The manuscript management system is completely online and includes a very quick and fair peer-review system, which is all easy to use. Visit $\mathrm{http}: / / \mathrm{www}$.dovepress.com/testimonials.php to read real quotes from published authors.

Submit your manuscript here: http://www.dovepress.com/drug-design-development-and-therapy-journal 